\title{
THE PATTERN OF THE FREQUENCY OF HBSAG, HBEAG, ANTI-HCV AND ANTI-HBE IN PATIENTS WITH HAEMOGLOBIN GENOTYPE HBSS AND HBSC IN A RURAL COMMUNITY.
}

\author{
Mathew Folaranmi OLANIYAN \\ School of Medical Laboratory Technology, Baptist Medical Centre, P.M.B 43, \\ Saki - Oyo state, Nigeria. E-mail- olaniyanmat@yahoo.com
}

\begin{abstract}
Sixty HbSS sickle cell anaemic patients aged $17.45 \pm 10.1$ years $($ Female $=30$, Male $=30)$ and sixty HbSC sickle cell disease patients aged 20.6 \pm 11 .0years $($ Female $=30, M a l e=30)$ were recruited for the investigation. Haemoglobin genotype of each of the patient was determined by electrophoresis. HepatitisB's' antigen, HBeAg,anti-HBe, and anti-HCV in patients' plasma were determined by Enzyme Immunoassay.

The frequencies of HBsAg, anti-HBe, HBeAg + HBsAg, HBsAg + antiHBe, in HbSS(6.7\%, 20\%, 13.3\%, and 20\% respectively) were higher than those of $\mathrm{HbSC}(5 \%, 8.3 \%, 5 \%$, and $3.3 \%$ respectively). The frequency of anti-HCV + anti-HBe in HbSC was higher compared with that of HbSS patients ( $3.3 \% \mathrm{Vs}$ 0\%). The frequency of $\mathrm{HBeAg}$ in female HbSS and HbSC patients was higher than their male counterparts.( HbSS:16.7\%Vs 10\%;HbSC:6.7\% Vs 3.3\%).Higher frequency of HBsAg was found in HbSS male patients than the females (26.7\% Vs 13.3\%).The frequency of anti-HBe in HbSS male patients and HbSC female patients was higher than those of HbSS female patients and HbSC male patients respectively( HbSS:10\% Vs 3.3\%; HbSC: 10\% Vs 6.7\%).The frequency of HBeAg+ HBsAg obtained in HbSS male patients and HbSC female patients was higher than the results obtained from $\mathrm{HbSS}$ female patients and HbSC male patients (HbSS: 16.7\% Vs 10\%; HbSC:6.7\% Vs 3.3\%).The frequency of HBsAg + anti-HBe in HbSS female patients was higher than in HbSS male patients. $(23.3 \% \mathrm{Vs} 16.7 \%)$. None of the patients plasma was found to contain both HBeAg + anti-HBe.

This research work has therefore been used to examine the pattern of $\mathrm{HBeAg}, \mathrm{HBsAg}$, anti-HCV, and anti-HBe in the plasma of patients with haemoglobin genotype $\mathrm{HbSS}$ and $\mathrm{HbSC}$ in rural community.
\end{abstract}

KEYWORDS: Pattern, Frequency, HepatitisB, Hepatitis C, Antibody, Surface ('s') and Envelope ('e') antigens.

\section{INTRODUCTION}

Clinically significant abnormal hemoglobin that can be found in tropical countries include $\mathrm{HbS}, \mathrm{HbC}$, $\operatorname{HbD}$ and $\operatorname{HbE}(1,2,3)$

Haemoglobin $\mathrm{S}$ is formed when valine replaces glutamic acid in the $\beta$ globin chain (6th amino acid osition) of haemoglobin. In deoxygenated state $\mathrm{HbS}$ has poor solubility forming polymers in red cells. Polymerization leads to changes in the red cell membrane and metabolism, causing the cells to become rigid and distorted with a sickle cell shape. $(1,3)$. The sickle cells adhere to vascular endothelium and to one another blocking small blood vessels. They become trapped in the cell spleen and haemolyse easily (3).

The term sickle cell disease is used to describe sickle cell anaemia ( $\mathrm{HbSS}$ ) and the range of $\mathrm{HbS}$ related disorders of similar clinical severity e.g. when $\mathrm{HbS}$ is inherited with $\mathrm{HbC}, \mathrm{HbD}$ or $\mathrm{HbO}$. Sickle cell can also occur when $\mathrm{HbS}$ is inherited with $\beta^{\text {o }}$ thalassemia gene.

Haemoglobin $\mathrm{C}$ is found in West Africa. It is formed when glutamic acid is replaced by lysine in the $\beta$ globin chain. Homozygous inheritance causes mild haemolytic anemia and splenomegaly. (3). 
When $\mathrm{HbC}$ is inherited with $\mathrm{HbS}(\mathrm{HbS}+\mathrm{C})$, the condition can cause symptoms similar to, but less severe than sickle cell anaemia (4).

Splenomegaly is more common in HbSS than HbSC disease, in some patients it causes only mild haemolytic anemia. (3).

The clinical features of sickle cell disease, which include sickle cell anaemia (HbSS) and $\mathrm{HbS}$ related disorders such as HbSC are:- haemolytic anaemia, jaundice, fever, painful swelling of hands and feet skeletal changes, painful infarcts, pulmonary complications, kidney damage, leg ulcers, increased risk of salmonella and pneumococcal infection, visual impairment, immune function impairment, gallstones, haemolytic and aplastic anemia. (3).

Hepatitis "e" antigen or HbeAg is known to be intimately associated with Hepatitis B virus - HBV replication and the presence of infectious Dane particles in the blood. It appears soon after HbsAg and persists for a short time, disappearing when recovery being. Persistence of e antigen indicates chronic liver disease. $(3,4)$.

Antibody to HbeAg (anti-HBe) may be found in the convalescence stage and often in chronic hepatitis and the carrier states (5).

The detection of HbsAg in the serum indicates an infection caused by the hepatitis B virus. It is the first marker to appear and may be observed 2 to 3 weeks before the clinical and biological symptoms of the disease $(5,6)$. Hepatitis B surface antigen (HbsAg) persisting beyond 6 months in serum denotes chronic hepatitis. $(3,6,7)$. Hepatitis (virus of $\mathrm{HCV}$ is an envelope RNA virus. Antibodies directed to the major immunodominant determinants of the viral proteins are detected in patients infected with HCV early in the course of infection $(8,9)$ The diagnosis of hepatitis $\mathrm{C}$ infection is usually made serologically by detecting anti-HCV $\operatorname{IgG}$ in the serum. $(5,8,9)$. Most patients infected with HCV become carriers. Antibody is detectable $6-8$ weeks after infection $(8,9)$.

This present research work was therefore designed to examine the serological pattern of anti-HCV, HBsAg, $\mathrm{HBeAg}$ and anti-HBe in patients with $\mathrm{HbSS}$ and $\mathrm{HbSC}$ in rural community.

\section{MATERIALS AND METHODS}

Participants: - Sixty HbSS sickle cell anaemic patients (Female $==30$, Male $=30)$ aged $17.45 \pm$ 10.1years and sixty participants with HbSC genotype $($ female $=30$, male $=30)$ aged $20.6 \pm 11.0$ years were recruited from three Local Governments; Saki-West, Saki-East and Atisbo) in Oke-Ogun, the Northern part of Oyo State, Nigeria for the study.

\section{MATERIALS}

Sample:- Five milliliters of blood was collected from each of the participants and preserved in NaEDTA anticoagulant bottles. The plasma was extracted from each of the blood samples for the senelogical studies while the red cells was used for haemoglobin genotype.

\section{METHODS:-}

(a) Haemoglobin genotyping was carried out by electrophoresis described by Cheesbrough ${ }^{5}$ (2002).

(b) Hepatitis $\mathrm{C}$ antibody detection in plasma/serum was carried out by Enzyme immunoassay for the determination of antibodies to Hepatitis $\mathrm{C}$ virus in serum and plasma using reagent kit of DIA. PRO, Diagnostic Bioprobes Srl Via Columella $n^{\circ}$ 31, 20128 Milano, Italy. E-mail diapro@tin.it

(c) Hepatitis B 'e'(envelope ) antigen and antibody in the plasma was detected by Enzyme immunoassay using the reagent kit 
of DIA.PRO, Diagnostic Bioprobes Srl via Columella n³1,20128 Milano, Italy. E-maildiapro@tin.it

(d) Hepatitis B surface (' $\mathrm{S}$ ') antigen detection in the plasma of the patients was carried out by

\section{RESULTS}

\section{TABLES 1A \& 1B}

The two tables present the serological pattern of $\mathrm{HBeAg}$, HBsAg, anti-HCV and anti-HBe in the sera of $\mathrm{HbSS}$ and $\mathrm{HbSC}$ patients. The frequency of anti$\mathrm{HCV}$ and anti-HbeAg found in $\mathrm{HbSS}$ and $\mathrm{HbSC}$ patients was the same. However higher frequency of anti-HBe and HBsAg was found in HbSS than HbSC patients.

None of the HbSS and $\mathrm{HbSC}$ patients was found to
Enzyme immunoassay Technique using MONOLISA AgHBs Plus reagent kit of BIORAD, 3, Bd Raymond Poincare 92430 MARNES LA COQUETIE.

Table 1a: Pattern of HBeAg, HBsAg, anit-HCV, and anti-HBe in the sera of $\mathrm{HbSS}$ and HbSC patients.

\begin{tabular}{|l|l|l|l|l|}
\hline Hb Genotype & Anti-HCV & Anti-HBe & HBeAg & HBsAg \\
\hline HbSS $n=60$ & $2(3.3 \%)$ & $4(6.7 \%)$ & $8(13.3 \%)$ & $12(20 \%)$ \\
\hline HbSC $n=60$ & $2(3.3 \%)$ & $3(5 \%)$ & $8(13.3 \%)$ & $5(8.3 \%)$ \\
\hline
\end{tabular}

Table 1b

\begin{tabular}{|l|c|c|c|c|}
\hline Hb Genotype & $\begin{array}{c}\text { HBeAg } \\
+ \\
\text { HBsAg }\end{array}$ & $\begin{array}{c}\text { HBsAg } \\
+ \\
\text { Anti-HBe }\end{array}$ & $\begin{array}{c}\text { HBeAg } \\
+ \\
\text { anti-HBe }\end{array}$ & $\begin{array}{c}\text { Anti-HCV + any } \\
\text { of HBsAg, } \\
\text { HBeAg, and anti- } \\
\text { HBe }\end{array}$ \\
\hline $\mathrm{HbSS} n=60$ & $8(13.3 \%)$ & $12(20 \%)$ & - & $0(0 \%)$ \\
\hline $\mathrm{HbSC} n=60$ & $3(.5 \%)$ & $2(3.3 \%)$ & - & $\begin{array}{c}\text { Anti-HCV + anti- } \\
\mathrm{HBe} 2(3.3 \%)\end{array}$ \\
\hline
\end{tabular}

Table-2a: Gender serological pattern of Anti-HCV, HBeAg HBsAg and anti-HBe in HbSS and HbSC patients.

\begin{tabular}{|l|l|l|l|l|l|}
\hline Gender & Hb Genotype & Anti-HCV & HBeAg & HBsAg & Anti-HBe \\
\hline Male & HbSS & $1(3.3 \%)$ & $3(10 \%)$ & $8(26.7 \%)$ & $3(10 \%)$ \\
\hline & HbSC & $1(3.3 \%)$ & $1(3.3 \%)$ & $4(13.3 \%)$ & $2(6.7 \%)$ \\
\hline Female & HbSS & $1(3.3 \%)$ & $5(16.7 \%)$ & $4(13.3 \%)$ & $1.3 .3 \%)$ \\
\hline & HbSC & $1(3.3 \%)$ & $2(6.7 \%)$ & $4(13.3 \%)$ & $3(10 \%)$ \\
\hline
\end{tabular}


Table -2b: Gender serological pattern of HbeAg + HbsAg, HbsAg + anti-HBe, HBeAg + anti-HBe, and anti$\mathrm{HCV}+$ any of HBsAg, HBeAg, and antiHBe in HbSS and HbSC patients.

\begin{tabular}{|l|c|c|c|c|c|}
\hline \multicolumn{1}{|c|}{ Gender } & Hb Genotype & $\begin{array}{c}\text { HBeAg } \\
+ \\
\text { HBsAg }\end{array}$ & $\begin{array}{c}\text { HBsAg } \\
+ \\
\text { anti-HBe }\end{array}$ & $\begin{array}{c}\text { HBeAg } \\
+ \\
\text { anti- HBe }\end{array}$ & $\begin{array}{c}\text { Anti-HCV + any of HbsAg, } \\
\text { HbeAg Anti-HBe }\end{array}$ \\
\hline Male & HbSS & $5(16.7 \%)$ & $5(16.7 \%)$ & - & $0(0 \%)$ \\
& HbSC & $1(3.3 \%)$ & $1(3.3 \%)$ & - & Anti-HCV + Anti-HBe 1 \\
Female & HbSS & $3(10 \%)$ & $7(23.3 \%)$ & - & 0 \\
$n=30$ & HbSC & $2(6.7 \%)$ & $1(3.3 \%)$ & - & Anti-HCV + Anti-HBe \\
& & & & & $1(3.3 \%)$ \\
\hline
\end{tabular}

\section{TABLES 2A AND 2B}

These tables present the result of serological pattern by gender of anti-HCV, $\mathrm{HBeAg}, \mathrm{HBsAg}$ and anti$\mathrm{HBe}$ in $\mathrm{HbSS}$ and $\mathrm{HbSC}$ patients. The frequency of anti-HCV in HbSS and HbSC male and female patients was the same but a higher frequency of $\mathrm{HbeAg}$ was found in $\mathrm{HbSS}$ and $\mathrm{HbSC}$ female patients than their male counterparts. Higher frequency of HBsAg was found in HbSS male patients than HbSS female patients. The same frequency of HBsAg was found in $\mathrm{HbSC}$ male and female patients. Male patients with haemoglobin genotype of SS have higher frequency of anti-HBe in their sera than their female counterparts. Higher frequency of anti-HBe was also found in $\mathrm{HbSC}$ female patients than their male counter parts.

Higher frequency of the presence of $\mathrm{HBeAg}$ and HBsAg in a single serum was found in HbSS males than $\mathrm{HbSS}$ females and in $\mathrm{HbSC}$ females than HbSC males. The frequency of the presence of both HBsAg and anti-HBe in a serum was higher in HbSS females than HbSS males but the same frequency was observed in male and female $\mathrm{HbSC}$ patients. Anti-HCV and antiHBe were found together in a single serum of on each of $\mathrm{HbSC}$ male and female.

\section{DISCUSSION}

Higher frequency of anti-HBe found in patients with Hbgenotype HbSS than HbSC may be associated with the higher incidence of hepatitis B infection in HbSS than HbSC due to higher frequency of anaemia in $\mathrm{HbSS}$ than $\mathrm{HbSC}$ a contributive factor to the possibilities of hepatitis B viral infection through transfusion of infected blood. $(3,5,6,7)$. The presence of this antibody indicates past hepatitis B infection and probably chronic, carrier or convalescence state. $(3,5,6,7)$. This supports the findings of this recent study that some patients with $\mathrm{HbSS}$ and $\mathrm{HbSC}$ has persistence of HbsAg (though more in the former) which indicates chronic hepatitis B infection in these patients as evidenced by the presence of both $\mathrm{HbsAg}$ and anti-HBe together in some sera. Sickle cell anaemia is also more severe compared with other haemoglobinopathes including $\mathrm{HbSC}$ which accounts for higher frequency of the presence of both HBsAg and anti-HBe together in some sera of HbSS than $\operatorname{HbSC}(2,3$, and 11).

Above explanations also hold for higher frequency of HBsAg, HBeAg + HBsAg, and HBsAg + anti- 
$\mathrm{HBe}$ in $\mathrm{HbSS}$ than in HbSC patients. This may also be associated with impaired immune function which is more in sickle cell anaemia compared to HbSC and other haemoglobinopathes. $(3,5,10)$. This makes them to be more susceptible to infections. The pathological basis for this susceptibility to infections is complex. Defective splenic function is the most important factor .There is also abnormalities of opsonization, alternate complement pathway, antibody production, leucocyte function, and cell-mediated immunity $(3,12,13$, and 14$)$

Presence of anti-HBe in serum in most cases indicates convalescence from Hepatitis B infection. (3). Presence of anti-HBe (or anti-HBe together with anti-HCV) in some sera of HbSC patients can be associated with this fact with reference to hepatitis $\mathrm{B}$ infection. Presence of anti-HCV in these patients indicates hepatitis $\mathrm{C}$ infection. $(2,5)$. None of the HbSS patients was found to possess anti-HBe + anti-HCV (or anti-HBe plus any of HBsAg, HB eAg) in their sera compared to HbSC patients that have frequency of $2 \%$. This may be attributed to the fatal severity of co- infections in HbSS than the HbSC patients. (3). This is also consistent with the fact that HbSC is less severe than HbSS patients and the impairment in immune function as explained earlier. $(3,5,10)$.

Higher frequency of $\mathrm{HBeAg}$ was found in $\mathrm{HbSS}$ and HbSC females than their male counterparts. Presence of $\mathrm{HBeAg}$ indicates viral replication and infectivity, also in most cases absence of antibody to ' $\mathrm{e}$ ' antigen to stop viral replication and infectivity $(6,7)$. This fact and findings can also be associated with the result of this study, that there was a higher frequency of anti-HBe in $\mathrm{HbSS}$ male than the females .Antibody to 'e' antigen in HbSC females was also higher than in the males this may be associated with the report of Walter and Engler(1995) ${ }^{14}$ that there is a difference between women and men in antibody response from immunization to hepatitis $\mathrm{B}$ virus.Lockshin and Volcker(1999) ${ }^{12}$ that sex hormone-control of some measures of adaptive and innate immunity, clinical inflammation, infection handling and healing rates differ between men and women. They further explained that not all autoimmune diseases are female predominant. Some thyroid, rheumatic and hepatic diseases have very high female / male ratios but the female/ male ratio is 1 for many autoimmune diseases and $<1$ for some. Female / male ratios measure incidence commonly cited sex discrepant autoimmune diseases do not differ in severity between the sexes. (12).

The frequency of HbsAg was found to be higher in HbSS male patients than in HbSS females is not consistent with the report of Walter and Engler ${ }^{14}$ that women in military may have an increased hepatitis B infection.

The frequency of HbeAg $+\mathrm{HbsAg}$ in HbSS males was higher than the HbSS females, and higher frequency of $\mathrm{HbeAg}+\mathrm{HbsAg}$ was also found in HbSC females than HbSC males. These may be attributed to the fact that there is a difference between women and men in antibody response from immunization to hepatitis B. (14). Infection handling and healing rates differ little between men and women (12). Antigens's' and 'e' to hepatitis B are cleared on the production of antibodies directed to the two antigens. $(6,7,10)$

Higher frequency of HBsAg + Anti-HBe was found in $\mathrm{HbSS}$ females than HbSS males. This may indicate carrier state and that the virus (Dane particle) is not replicating and infective because of the presence of anti-HBe.( 6,7,10). It may also indicate chronic infection because of the persistence 
of HBsAg in their sera. $(5,6,7,10)$. The gender difference can be attributed to the reports of Lockshin and Volcker (1999) ${ }^{12}$ and Walter and Engler (1995) ${ }^{14}$

\section{REFERENCE}

1. Dacie J. V. and Lenis S. M. Practical Hematology. Published by Churchill's Livingstone London $4^{\text {th }}$ edition Pp. 400 -520.

2. Brain Maegraith. Adams and Maegraith Clinical Tropical Diseases. English Language, Book Society/Blackwell Scientific Publications. Printed and Bound in Great Britain By Alden Press Oxford (1985). ELBS eight edition; $\mathrm{Pp}-140-155$.

3. Kumar Praveen and Clark Michael. Clinical Medicine. Printed in U. K. by Bath Press ltd (2202) Fifth edition Pps 100-506.

4. John Macleod: David Son's Principles and Practice of medicine. The English Language Book Society and Churchill Livingstone. (1981) $13^{\text {th }}$ ELBS edition. Pp 1-23, 376-421, 534-604.

5. Cheesbrough Monica. District Laboratory Practice in Tropical Countries Part 2. Cambridge University press, U.K (2002) Cambridge Low Price edition, Pps 246-266, 332-340.

6.

7. Lai C. L. Ratziu V. Yuen. M. F. Poynard T. Viral hepatitis B Lancet (2003): 362: 940 -961.
8. Lee W. M. Hepatitis B virus infection. N. Engl.J. Med (1997): 337 (24): 1733-45.

9. Alter M. J Epidemiology of hepatitis C. Hepatology 1997: 26: 625-655.

10. De France O. R. Molecular virology of the hepatitis C virus. Journal of Hepatology, 1999: 31:43-46

11. Salimonu L. S; Mohammed. I, Oyeyinka G. O. Arinola O. G and Okafor G. O. Basic immunology for students of Medicine and Biology. College press and Publishers, Jericho GRA Ibadan. Nigeria (2003) First edition Pp 2-12, 111-116, 170 - 196.

12. Black well Synergy - J. Travel Medicine volume 13. issues $2 \mathrm{Pp} 115$ - 125 available at;www.blackwell-synergy.com/doi/abs/1

13. Lockshin M. D., Barbara Volcker sex and immunity. J. Biomed. 1999 available at www.biomedcentral.com/abstracts/AAO

14. Pub Med News and Note Worthy. April 30, 2007 www.ncbi.nlm.nih.gov/entrez/query

15. Walter Peed, Engler Renata. J. protective immunity to Hepatitis B and S. pneumoniae in active duty women versus men. Dec. 1, 1995 Annual report. Pp 94-100. Available at www.strinet.dtic.mil/oai/oai 